\title{
Mesenchymal Stem Cell Secretome: Cell-free Therapeutic Strategy in Regenerative Medicine
}

\author{
Anna Meiliana ${ }^{1,2,}$, Nurrani Mustika Dewi ${ }^{2}$, Andi Wijaya ${ }^{1,2}$ \\ ${ }^{1}$ Postgraduate Program in Clinical Pharmacy, Padjadjaran University, Jl. Eijkman No.38, Bandung, Indonesia \\ ${ }^{2}$ Prodia Clinical Laboratory, Jl. Cisangkuy No.2, Bandung, Indonesia \\ *Corresponding author. E-mail: anna.meiliana@prodia.co.id
}

Received date: May 13, 2019; Revised date: Jun 14, 2019; Accepted date: Jun 17, 2019

\section{Abstract}

$\mathrm{B}$ ACKGROUND: Mesenchymal stem (stromal) cells (MSCs) have a multipotent character, able to differentiate into several cell types, thus MSC serve as a cell reservoir for regenerative medicine. MSC therapeutic potency more associated to their immunosuppressive and anti-inflammatory properties rather than the multipotency, by its mechanism to secrete soluble factors with paracrine actions.

CONTENT: MSC paracrine function was known to mediated partly by extracellular vesicles (EVs), which were released predominantly from the endosomal compartment contained in MSC secretome. EV contain a cargo bring micro RNA (miRNA), messenger RNA (mRNA), and proteins from their cells of origin, propose EV as a novel alternative to whole cell therapies, regarding the benefit of EV in safety and easier storage compared to the parent cells.

SUMMARY: The discovery of EVs including exosomes in MSC secretome as key of stem cells beneficial function lead to the future hope of using cell-free regenerative therapies.

KEYWORDS: MSC, secretome, conditioned media, extracellular vesicle, exosome

Indones Biomed J. 2019; 11(2): 113-24

\section{Introduction}

Within tissues, cells coordinating need a proper communication. Different cell types can communicate each other by soluble factors (1), cell-to-cell interactions mediated by adhesion molecules including cytonemes that connect neighboring cells for exchange surface-associated molecules, or by tunneling nanotubules that establish conduits between cells which more than only transferring surface molecules but also cytoplasmic components.(2,3)

Extracellular vesicles (EVs) are a heterogeneous collection of membrane-bound carriers release from a cell with complex cargos, including proteins, lipids and nucleic acids (e.g., cell specific antigens, surface markers, adhesion molecules, ligands, receptors, enzymes, micro RNAs (miRNAs), long non-coding RNAs (lncRNAs), messenger
RNAs (mRNAs), growth factors, etc.).(4-6) EVs consist of exosomes and microvesicles, which originate from the endosomal system or which are shed from the plasma membrane, respectively.(7) For a long time, microvesicles regarded as inert cellular debris or as the consequence of cell damage or the result of dynamic plasma membrane turnover, until recently some studies suggested them to be involved in cell communication. $(8,9)$ In the last decade, many studies in physiology and diseases considered EVs as significant factors in inflammation and immune responses, antigen presentation, cancer progression and metastasis, immunomodulation, coagulation, tissue regeneration, organ repair, cell-cell communication, senescence, proliferation and differentiation in the body (10-12).

Exosomes perform many stimulatory or inhibitory functional outcomes including cell proliferation, apoptosis, cytokine production, immune modulation, and metastasis, 
as their bioactive cargo is capable to modify the activity or properties of specific target cells.(13-17) Despite of the conventional one, exosomes add an alternative mode of paracrine and endocrine communication strategies of direct cell-cell contact and soluble, receptor-targeted hormones and cytokines.(18) Therefore, exosomes are proposed to play an important albeit role in human physiology and homeostasis, pathogenesis of major human diseases, and also become a promising source of disease-associated biomarkers and outright may be used as cell-free delivery vectors for targeted biological therapies. $(19,20)$

Regenerative medicine aims to restore any damaged, malfunctioning, or missing tissue. There are currently three approaches in regenerative medicine: first, cell-based approach, where cells are directly administered to restore a tissue through the cells themselves and/or the cells' paracrine functions; secondly, classical tissue engineering, using a combination of cells and a biodegradable scaffold to form a tissue; and lastly material-based approaches, which rely on bio-degradable materials, often functionalized with cellular functions.(9) Increasing evidences support that many observed effects of stem cell therapies were employed by the cells' secretion products like growth factors and cytokines, and implanted cells alone cannot survive for long without bioactive factors they produce.(6-9) This secreted paracrine factors drag a major interest to discover new therapeutics that stimulate local tissue regeneration and in tissue engineering as well.(21-23)

\section{Biogenesis, Secretion and Functions of Exosomes and Other Extracellular Vesicles}

EVs consist of exosomes, microvesicles (also known as shedding vesicles, ectosomes, and nanoparticles) and apoptotic bodies, with different size and biogenesis. By some stimulus, cell plasma membrane inwardly budding to form early endosomes. The late endosomes then subsequently form multivesicular bodies (MVBs) through characterized pathway that relies on endosomal-sorting complexes required for transport (ESCRT). ESCRT helps in MVBs invagination and cleaving the buds to form intraluminal vesicles (ILVs). During this process, certain proteins are incorporated into the invaginated membrane, later generating the parent cells' reflection in exosomes.24-29 Most ILVs are released into the extracellular space upon MVBs fusion with the plasma membrane, which are referred to as exosomes. Exosomes are the smallest EVs, with a diameter of $30-150 \mathrm{~nm}$, and have an endosomal origin, compare to larger microvesicles $(100 \mathrm{~nm}-1 \mathrm{~mm})$ and apoptotic bodies $(1-5 \mathrm{~mm})$ result from the direct outward budding and fission of the plasma membrane.(30-32) Figure 1 shows the assembly, release and action process of EVs.

Typical exosomal marker proteins are tetraspanins such as cluster of differentiation (CD)9, CD63, and CD81; cytoplasmic proteins such as actin, annexins, and Rasassociated binding (RAB) proteins; MVB biogenesis molecules such as Alix and tumor susceptibility gene (TSG)101, also heat-shock proteins such as heat shock protein (HSP)70 and HSP90.(33-36) Other components defined in exosomes can also be cell-type specific such as $\sim 1300$ mRNAs (i.e., about $10 \%$ of mRNAs from the parent cells) and 120 miRNAs, various other types of RNAs and of double-stranded DNA fragments, phospholipids which form the lipid bilayer, identified as about 3500 proteins and 2000 lipid species.(37-43) The presence of so many molecules is not in one single vesicle but instead those bulk materials were represented in several populations of microvesicles or exosomes as an exosome pellet or a microvesicle pellet.(4144). So, there may be some distinct biogenesis pathways for different populations.(45)

More recently, another pathway for exosome biogenesis was characterized which involving the syndecan/syntenin complex and requires the activity of the phospholipase D (PLD)2.(16) PLD2 inactivation prevents the MVBs intraluminal vesicles formation (Figure 2). PLD2 is activated by the small G protein Arf6, and PLD activities known to coordinate the process between exosomes and microvesicle formation. Arf6 activity involved in microvesicle formation by leading to the localization of the myosin-light chain kinase at the neck of the newly forming vesicles, to promote the fission to release them from the plasma membrane.(22)

The protocol for reticulocyte exosomes purifying first developed to separate exosomes from tissue culture conditioned medium $(46,47)$ and then improved to purify these vesicles from antigen-presenting cells based on differential centrifugation, where the smallest vesicles (including exosomes) are sedimented by ultracentrifugation at $100,000 \times \mathrm{g} .(7,37,43)$ However, the ultracentrifugation is not a proper purification, because it open the possibility for other vesicles with similar size as protein aggregates. Many current commercially available methods without ultracentrifugation claims to be fast and simple, either (presumably) by polymer-based precipitation or immunocapture by antibody-coated beads. Nonetheless, these new tools still need to be validated for any kinds 


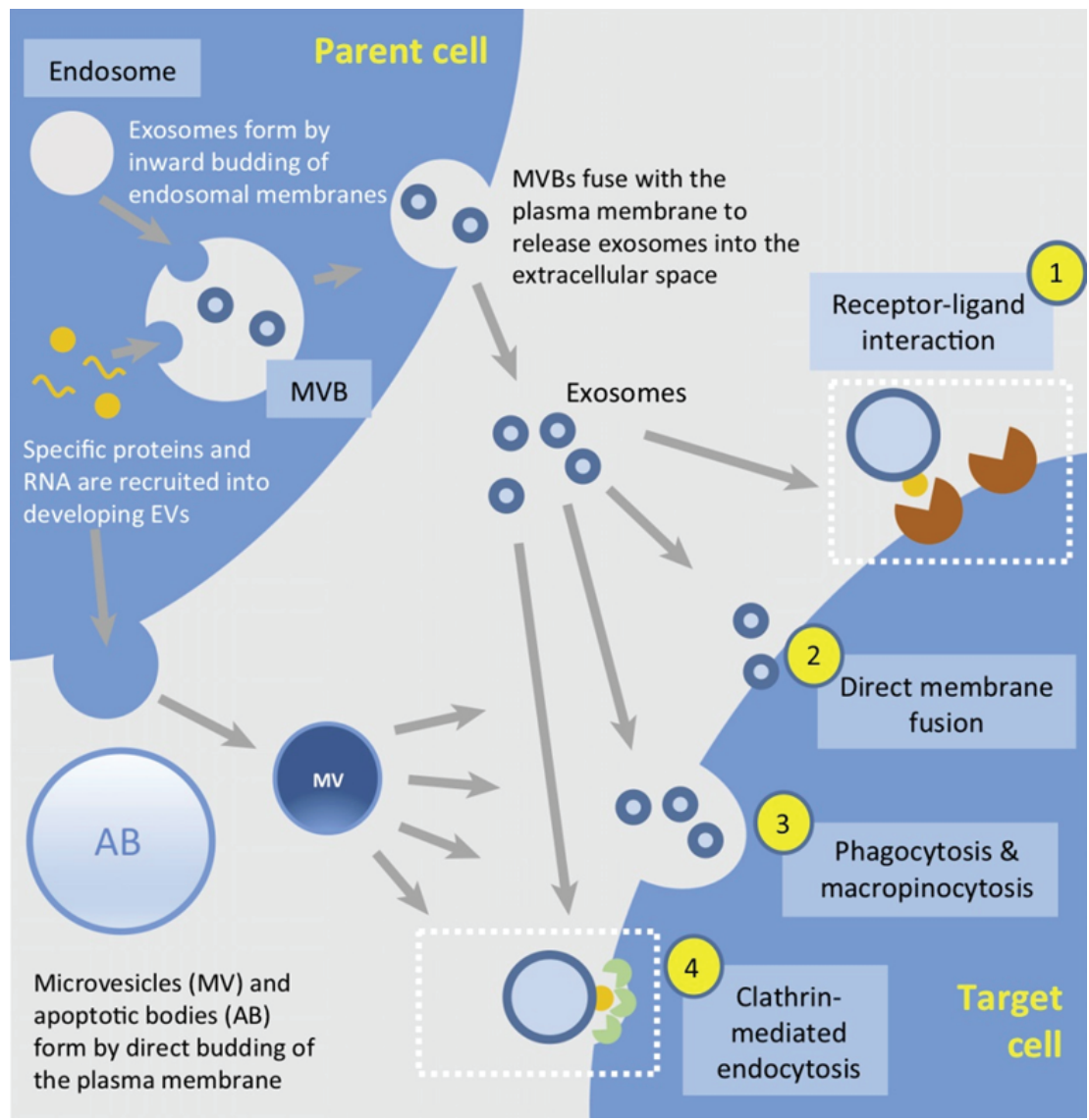

Figure 1. Assembly, release and action of EVs.(18) (Adapted with permission from Elsevier). of vesicles were precipitated.(7) Overall composition of extracellular vesicles is shown in Figure 3.

Exosomes are secreted by various cell types including immune cells, neural and stem cells to interact with other cells, involved in many physiological processes such as antigen presentation (48), transfer of RNA (13) or tissue repair (49), resulting in physiological changes (48). This explain exosomes and its associaton with the progression of disease conditions including neurodegenerative disease, cardiovascular diseases and cancer (50-53), raising the interest to isolate exosomes as the active components of conditioned medium from human embryonic stem cellderived MSC (49). Clinical studies performed the injection of dendritic cell-derived exosomes in melanoma patients showed tumor regression and long-term stabilization.(28) Exosomes first time proved to be used as delivery vehicle for nucleic acid cargos was exploited recently during Alzheimer's disease. $(54,55)$

\section{Stem Cells in Regeneration Medicine}

Regenerative medicine is defined as various approaches and actions to replace lost tissues with new tissues/cells or enhance regeneration of damaged tissues in a broad spectrum of indications (e.g., myocardial infraction, osteoarthritis, lung diseases, acute kidney injuries, chronic wounds, muscular dystrophies, bone and cartilage defects, etc.).(9,10,56-58) There are different strategies towards tissue/organ regeneration, from cell transplantation to utilizing biomaterials alongside stem cell therapy, which are called tissue engineering.(59)

Mesenchymal stem (stromal) cells (MSCs) are multipotent, non-hematopoietic adult stem cells, with the potential to differentiate and/or transdifferentiation into osteoblasts, chondrocytes, and adipocytes as well as endothelial, cardiovascular, and neurogenic cell types, thus appeared to be the plausible solution for tissue repair and wound healing.(60-63) MSCs can be isolated from bone marrow (BM), umbilical cord, placental or adipose tissue, with the capacity for ex vivo expansion and ethical acceptable.(61-64) Despite of their direct role in tissue regeneration, the potency of MSC found to associated with its anti-inflammatory and/or immunosuppressive properties, as demonstrated by some studies that the differentiation capability of MSCs did not predominant the mechanisms for promoting or repairing the tissue damage in most disease but instead they found a short-lived paracrine mechanisms 
among MSCs therapeutic actions.(65-69) Extensive studies explore more MSCs use as regenerative agents in spinal cord injury, multiple sclerosis, Alzheimer's disease, liver cirrhosis and hepatitis, osteoarthritis, myocardial infarction, kidney disease, inflammatory bowel disease, diabetes mellitus, knee cartilage injuries, organ transplantation, and graft-versus-host disease (http://www.clinicaltrials.gov; accessed November 2014).(66)

In acute kidney injury (AKI), MSC administration give their benefit not for differentiating into a tubular or endothelial cell phenotype, but by increasing antiinflammatory regulation and organ-protective mediators including interleukin (IL)-10, basic fibroblast growth factor (bFGF), transforming growth factor (TGF)- $\alpha$, and B-cell lymphoma 2 (Bcl-2).(70) The paracrine nature of cytoprotection in the immediate vicinity of administered MSCs in AKI. In this study, the renotropic factors, (hepatocyte growth factor, and insulin-like growth factor 1) induced by MSCs, showed to decrease apoptosis and stimulate proliferation of renal epithelial cells.(71) However, the precise mechanism of MSC's paracrine fashion is not fully understood. Some data suggested an array of soluble factors and large numbers of extracellular vesicles (EVs) released by MSCs, bring up possibilities that EVs to some degree, mediating the communication between exogenously administered MSCs and other stem cells and generating the complex paracrine regenerative actions.(72-74)

\section{Therapeutic Potential of The MSC Secretomes}

Many growing evidences supported the MSCs paracrine actions in improving their positive clinical outcome, along with the findings of a wide range of chemokines, cytokines, growth factors and EVs secreted by MSCs, collectively termed as secretome which involved in cell viability, proliferation, angiogenesis, and immune responses.(75) The secretome is defined as the set of factors/molecules secreted to the extracellular space.(76-83) Secretome of individual cells and tissues is specific, and changes in response to fluctuations in physiological states or pathological conditions. $(23,84)$

MSC secretion also including vascular endothelial growth factor (VEGF), insulin-like growth factor (IGF)1 , bFGF, (TGF- $\beta 1$ ), nerve growth factor (NGF), placental growth factor (PGF), stromal-derived growth factor (SDF1/CXCL12), monocyte chemo-attractant protein-1 (MCP1/CCL2), IL-6, IL-8, IL-10 and IL-13.(85-88) Different population of MSCs can secret different secretome, for instance adipose-derived MSCs were reported to have higher mRNA expression of VEGF-D, IGF-1 and IL8 , while dermal sheath and dermal papilla-derived cells secreted higher concentrations of CCL2 and leptin.(89) placenta-derived MSCs increased expression levels of

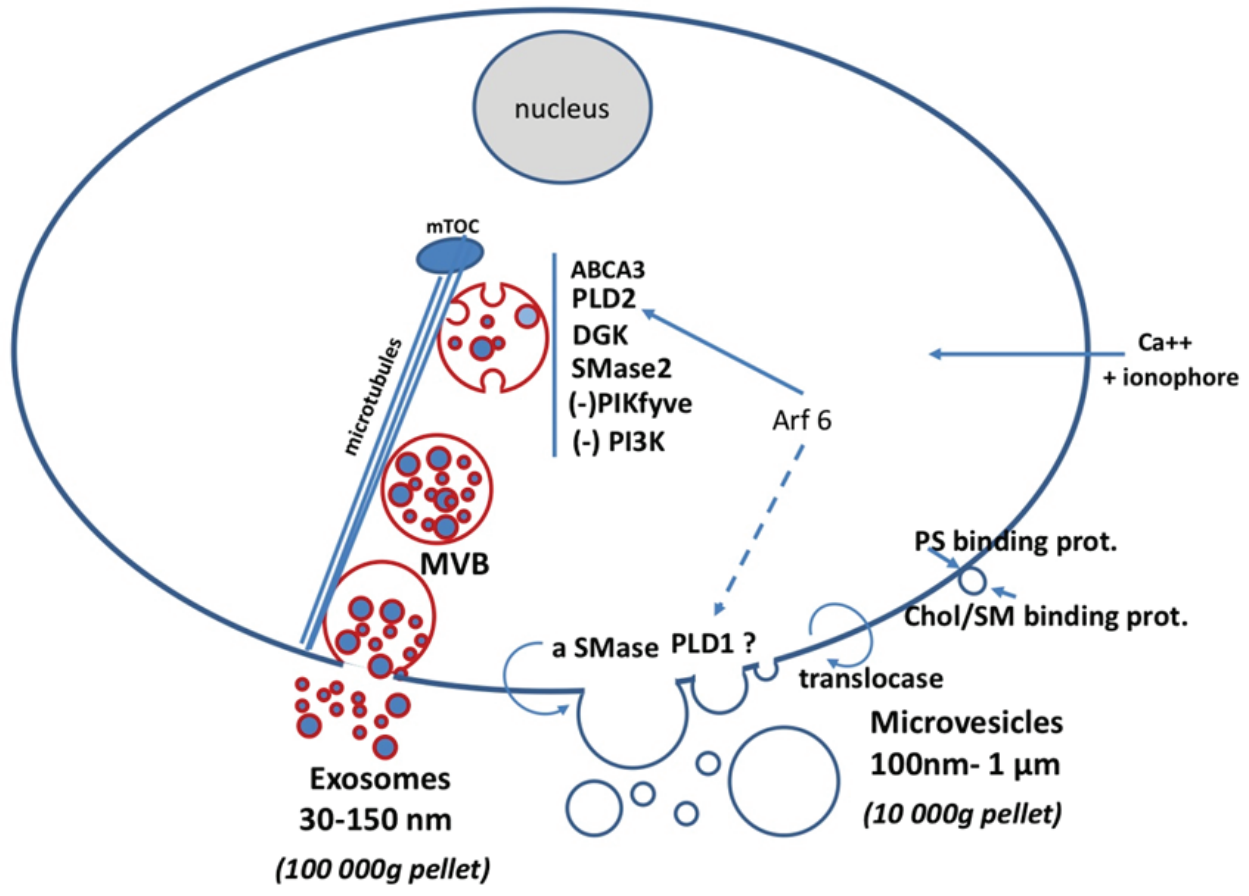

Figure 2. Lipid-related partners of exosome and microvesicle biogenesis.(45) (Adapted with permission from American Society for Biochemistry and Molecular Biology). 


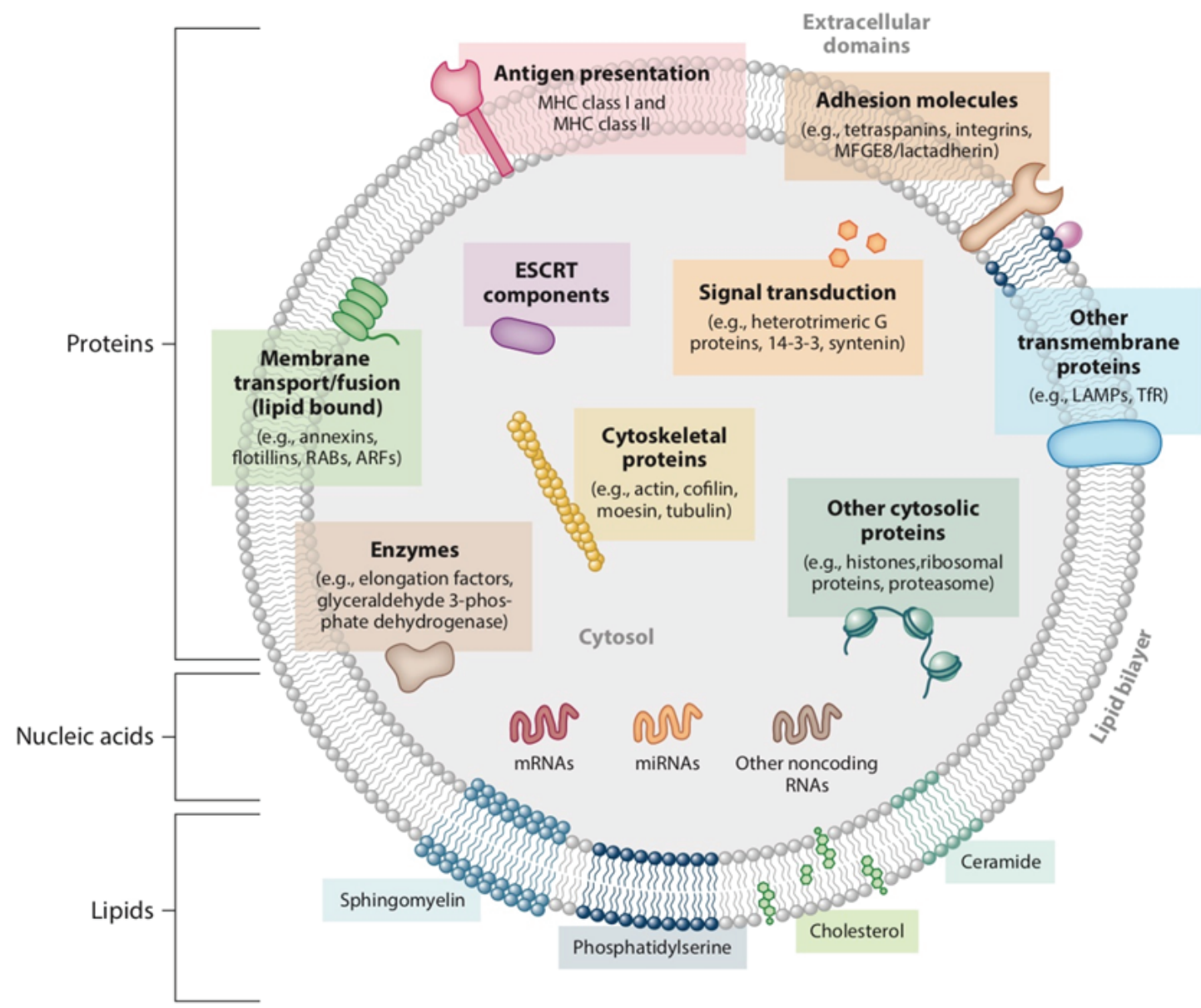

Figure 3. Overall composition of EVs.(7) (Adapted with permission from Annual Reviews). MHC: major histocompatibility complex; MFGE8: milk fat globule-EGF factor 8; ESCRT: endosomal-sorting complexes required for transport; LAPM: ysosome-associated membrane glycoproteins; TfR: transferrin receptor; RAB: Ras-associated binding; ARF: ADP-ribosylation factor.

hepatocyte growth factor (HGF), bFGF, IL-6, IL-8, IL-1 $\alpha$ and IL-1 $\beta$, while in bone marrow-derived MSC VEGF-A, NGF and angiogenin were higher.(90) The MSC secretome therefore has great potential as a regenerative therapy for stroke due to their potency in promoting angiogenesis and neurogenesis, prevent apoptosis and modulate inflammatory responses so many attempts were taken to enhance the MSC secretome (Figure 4).(75)

There are some advantages in using cell-free therapies such as MSC-sourced secretome in regenerative medicine compared to the stem-cell itself, i.e., secretome application regards to be safer related to transplantation of living and proliferative cell populations in the matter of immune compatibility, tumorigenicity, emboli formation and the transmission of infections; the evaluation protocol for safety, dosage and potency of MSC-sourced secretome can be done following to conventional pharmaceutical agents; secretome can be stored for a long period without potentially toxic cryopreservative agents or loss of product potency (91-93); it is more economical and practical and avoids invasive cell collection procedures (94); possible for tailor-made mass production, providing a convenient source of bioactive factors; has lower cost and time for production, thus off-the-shelf secretome therapies could be immediately available for treatment of urgent conditions such as cerebral ischemia, myocardial infarction, or military trauma; and the biological product is available for modification adjust to desired therapeutic cell-specific effects.(23) By preventing cell apoptosis, modulating the inflammatory response and promoting endogenous repair mechanisms such as angiogenesis and neurogenesis, MSC secretome can promote tissue repair.(75)

\section{Prospect of MSC Conditioned Medium in Regenerative Medicine}

Cell-based therapy using stem cells is a promising option for treating ischemic diseases, including ischemic heart diseases and chronic limb ischemia.(95,96) However, 


\section{Strategies to Enhance the MSC Secretome}

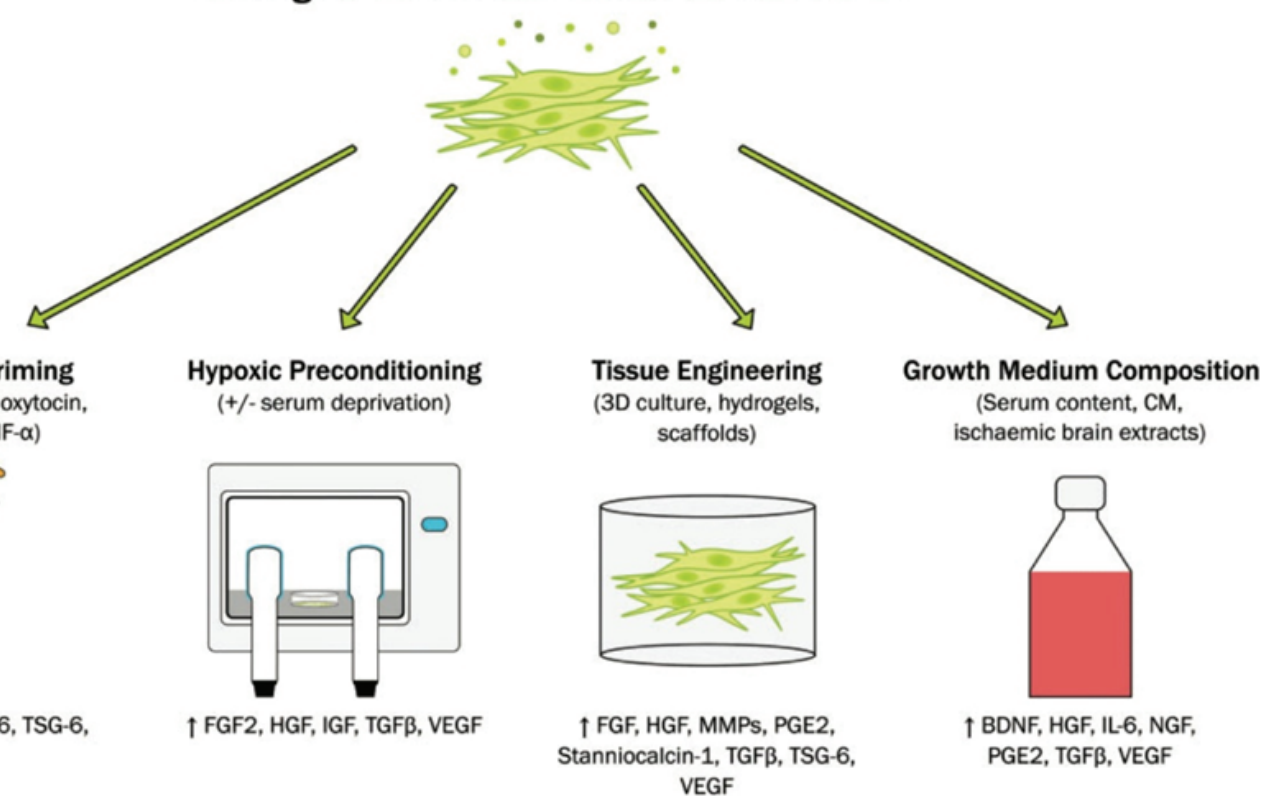

Hypoxic Preconditioning (FGF, IL-1, IFN-y, oxytocin, poly(l:C), TNF- $\alpha)$

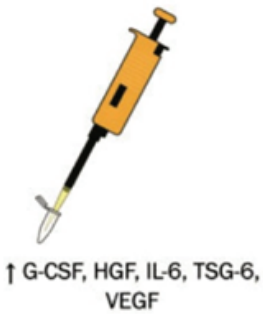

Tissue Engineering (3D culture, hydrogels, scaffolds)

$\uparrow$ FGF, HGF, MMPs, PGE2, VEGF
(Serum content, CM,
,

(n)

Figure 4. Summary of in vitro approaches that have been utilized to enhance the therapeutic potential of mesenchymal stem cell secretome.(75) (Adapted from Sage Publication)

the cell-based therapy efficacy was limited by the poor engraftment $(97,98)$ and the potential cancer risk after stem cell transplantation $(99,100)$. Here, stem cell conditioned medium (CM) offers a solution for a safer option.(101)

Recent evidences showed that even the secreted factor (i.e., secretome, microvesicles, or exosomes) alone without the cell may repair damaged tissue in various conditions. The use of secretome found in the medium where the stem cells are cultured, or so called CM have advantages more than what we have mentioned before, as it is devoid of cells; there is no need to match the donor and the recipient to avoid rejection problems.(102) The use of $\mathrm{CM}$ for therapy is very appealing and may be booming in the near future, as studies on the use of CM for various diseases are accumulating.(101,103-105) The fact that stem cells secrete various growth factors was also shown by various proteomic studies, which revealed the presence of various growth factors and other cytokines in the CM.(106-109) To use CM for various human diseases, production method of the CM needs to be standardized in terms of the type and number of cells that were needed to produce the $\mathrm{CM}$, culture medium and condition, and $\mathrm{CM}$ processing. In addition, the volume and mode of delivery are also important. As various studies used various numbers and type of cells and various doses of $\mathrm{CM}$, it is important to know the number of cells that yielded the $\mathrm{CM}$ for one application, which may be interpolated for human studies.
In addition, for translation into patients, it is very important to analyze and to note the various cytokine contents of the various conditioned media. Further, for every CM with known cytokine content, validation of its use on various diseases needs to be conducted. Finally, the possibility of promotion of existing cancer should be tested for every CM, and caution should be taken before $\mathrm{CM}$ therapy to ensure that the recipient is free from cancer. Advantages of production of various $\mathrm{CM}$ for patients lie in the possibility of mass production by pharmaceutical companies, when production methods have been standardized. Conditioned media are not like stem cells that need a good manufacturing practice (c-GMP) facility to be applied to patients.(110) When CM has been packaged properly, it can be transported easily as drugs and does not need cryopreservation, such as that the stem cells need. However, compared to stem cells that may survive for a rather long period, CM needs to be given more frequently, as cytokines' and growth factors' halflives are mostly shorter.(111,112), which is a disadvantage for the patients but will give more profit to pharmaceutical companies.(113)

There are various therapeutic applications for $\mathrm{CM}$, including anti-photoaging properties and accelerating the wound healing with fewer scars. Moreover, it plays an important role in inducing migration and angiogenesis, preventing muscle atrophy, possessing anti-fibrotic properties and regenerating capacities. It does help in 
suppressing proteolytic system and the ROS generation in muscle atrophied cells.(114-116) The diverse studies on the secreted factors derived from stem cells exhibited that the secreted soluble factors without the stem cells might provoke tissue repair in different conditions that involved in organ or tissue damage. $(113,117)$

CM obtained from ubmilical cord-MSCs (UC-CM) found to exert significant angiogenic and chemoattractant effects on progenitor cells, fibroblasts and stem cells, suggest a role of SDF-1/CXCR4 and MCP-1/CCR2 axes in UC-CM-induced migration. The local delivery of UC-CM may induce the recruitment of cells from the surrounding tissues and enhance the proliferation of these cells in injured tissue.(118) Recent findings suggest that MSC-CM have similar properties like MSCs and favorable antitumor characteristics as well. Therefore it is compelled to be applied for the generation of novel and targeted regenerative medicine (Figure 5).(117)

\section{MSC-derived Exosome for Cell-free Therapy}

Identification of exosomes revealed its unique protein and lipid contents, which can be used as positive markers. It mostly contain fusion proteins and transport proteins (annexins and flotilin), HSP70, CD's proteins (CD9, CD81), as well as phospholipases and other lipid related proteins.(119,120). In purpose of using MSC exosomes as cell-free regenerative medicine, the parameters of quality, reproducibility, and potency of their production should be considered well.(57)

Many techniques for exosome isolation has been developed with appreciable quantity and purity. Different technique exploits a particular trait of exosomes, such as their density, shape, size, and surface proteins to aid their isolation with the advantages and disadvantages of each. (121) Exosomes can be found in all body fluids, carrying specific information to their progenitor cells, thus exosomes is cheap, minimally invasive, and specific to be ideal biomarkers.(122,123) Many studies so far rationalize exosome as a novel form of a therapeutic intervention which is safer, cheaper, more accessible and potent, cell-free, and off- the-shelf therapy, although translation to clinical practice would require validation.(124) Studies was reported that hucMSC-Ex-mediated Wnt4 induces $\beta$-catenin activation in endothelial cells and exerts proangiogenic effects, make it prospect for use in cutaneous wound healing.(125) Another study demonstrated a cartilage regeneration in a full-thickness cartilage defect model in immunocompetent adult rats from human MSC exosomes (58), proof that exosomes also have a chance to alleviate OA via repairing and regenerating the damaged articular cartilage (126) In neurorestorative events after stroke and neural injury, exosomes showed as important intercellular players where either naturally occurring or engineered exosomes derived from stem/progenitor cells provide therapeutic benefits. $(72,127,128)$ Suggest that exosomes not only cross the

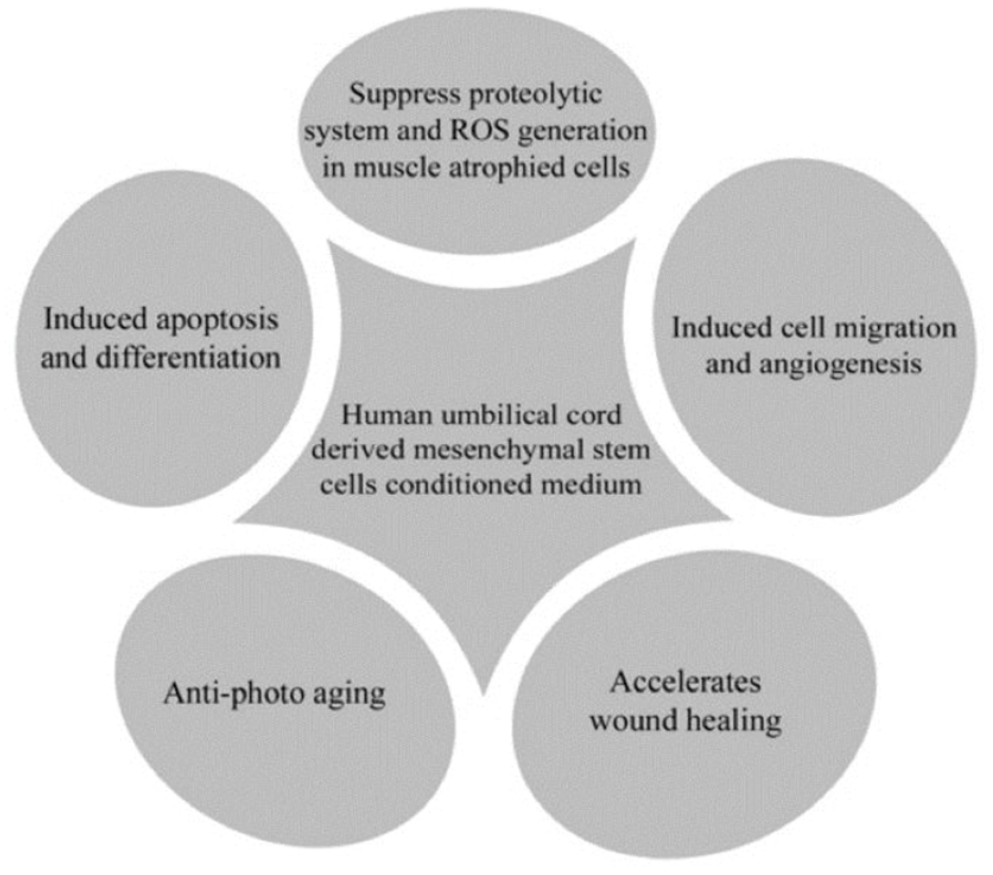

Figure 5. Clinical applications of conditioned medium (CM) derived from human umbilical cord-MSCs.(117) (Adapted with permission from International Journal of Hematology-Oncology and Stem Cell Research). 
Blood vessel

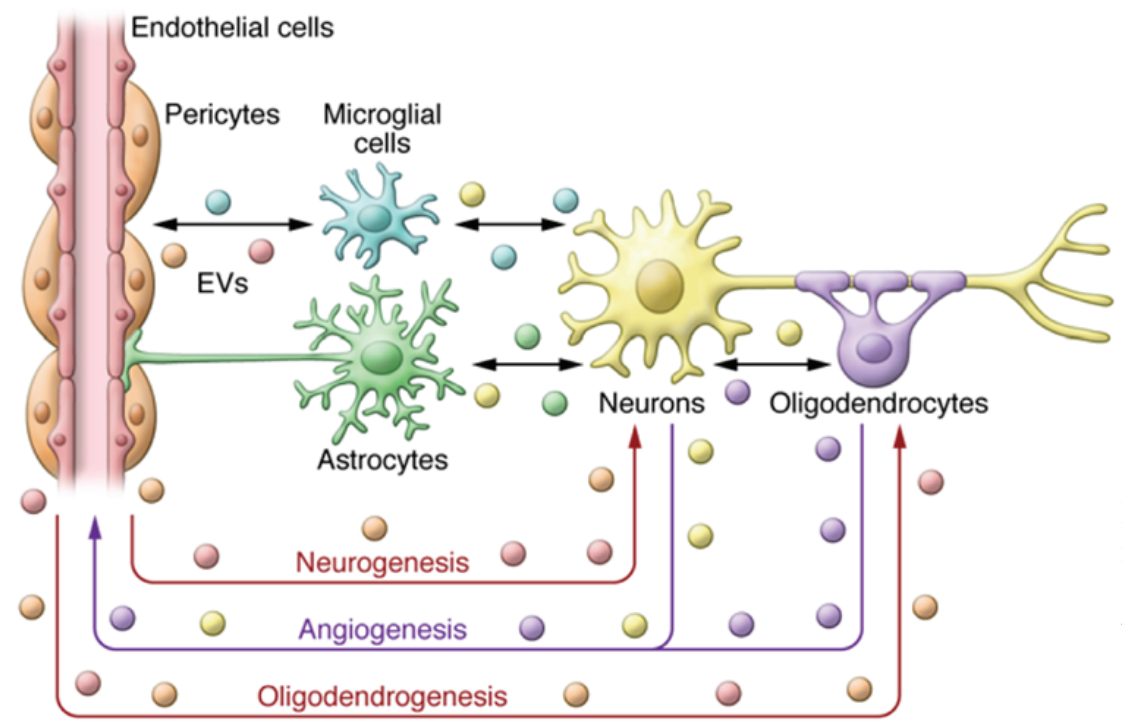

Figure 6. Potential of exosome-mediated intercellular communication in brain remodeling after stroke.(129) (Adapted with permission from American Society for Clinical Investigation).

blood brain barrier (BBB), but also deliver functional cargo to trigger gene expression in specific recipient cell types in the brain.(129)

In the case of ischemic injury, exosomes was known to improve heart function by stimulating neovascularization and restrain the inflammation response.(130) Many future studies will reveal the clinical potential of exosomes including their cargo property, targeting function and different sources of exosomes, to enable exosomes application in targeted tissue (Figure 6).(120)

\section{Conclusion}

Secretome-based approaches showed many potential advantages over the living cells themselves, including manufacturing, storage, handling, packaging, product shelf life and their potential as a ready-to-go biological therapeutic agent. Besides, exosomes also fulfill the requirements to be potential biomarkers of pathophysiology in many different diseases. However, we still need a clear consensus about the optimum culture conditions, separations, characterizations and stability and preconditioning strategies to maximize the regenerative potential of the MSC secretome.

\section{References}

1. Majka M, Janowska-Wieczorek A, Ratajczak J, Ehrenman K, Pietrzkowski Z, Kowalska MA, et al. Numerous growth factors, cytokines, and chemokines are secreted by human CD34(+) cells, myeloblasts, erythroblasts, and megakaryoblasts and regulate normal hematopoiesis in an autocrine/paracrine manner. Blood. 2001; 97: 3075-85.

2. Rustom A, Saffrich R, Markovic I, Walther P, Gerdes HH. Nanotubular highways for intercellular organelle transport. Science. 2004; 303: 1007-10.

3. Sherer NM, Mothes W. Cytonemes and tunnelling nanotubules in cell-cell communication and viral pathogenesis. Trends Cell Biol. 2008; 18 : 414-20.

4. Fuster-Matanzo A, Gessler F, Leonardi T, Iraci N, Pluchino S. Acellular approaches for regenerative medicine: on the verge of clinical trials with extracellular membrane vesicles? Stem Cell Res Ther. 2015; 6: 227. doi: 10.1186/s13287-015-0232-9.

5. Soleymani-Goloujeh M, Saberi S, Shckari F. Extracellular vesicles in regenerative medicine, a brief review. Mol Med Lab J. 2018; 2: 6-14.

6. Robbins PD, Morelli AE. Regulation of immune responses by extracellular vesicles. Nat Rev Immunol. 2014; 14: 195-208.

7. Ratajczak J, Wysoczynski M, Hayek F, Janowska-Wieczorek A, Ratajczak MZ, et al. Membrane-derived microvesicles: important and underappreciated mediators of cell-to-cell communication. Leukemia. 2006; 20: 1487-95.

8. Siekevitz P. Biological membranes: the dynamics of their organization. Annu Rev Physiol. 1972; 34: 117-40.

9. Camussi G, Deregibus MC, Bruno S, Cantaluppi V, Biancone L. Exosomes/microvesicles as a mechanism of cell-to-cell communication. Kidney Int. 2010; 78: 838-48.

10. Colombo M, Raposo G, Théry C. Biogenesis, secretion, and intercellular interactions of exosomes and other extracellular vesicles. Annu Rev Cell Dev Biol. 2014; 30: 255-89.

11. Bobrie A, Colombo M, Raposo G, Thery C. Exosome secretion: molecular mechanisms and roles in immune responses. Traffic. 2011; 12: 1659-68.

12. De Jong OG, Van Balkom BW, Schiffelers RM, Bouten CV, Verhaar MC. Extracellular vesicles: potential roles in regenerative medicine. Front Immunol. 2014; 5: 608. doi: 10.3389/fimmu.2014.00608.

13. Valadi H, Ekström K, Bossios A, Sjöstrand M, Lee JJ, Lötvall JO. Exosome-mediated transfer of mRNAs and microRNAs is a novel mechanism of genetic exchange between cells. Nat Cell Biol. 2007; 9: 654-9. 
14. Skog J, Würdinger T, van Rijn S, Meijer DH, Gainche L, Curry WT, et al. Glioblastoma microvesicles transport RNA and proteins that promote tumour growth and provide diagnostic biomarkers. Nat. Cell Biol. 2008; 10: 1470-6.

15. Hoshino A, Costa-Silva B, Shen TL, Rodrigues G, Hashimoto A, Tesic Mark M, et al. Tumour exosome integrins determine organotropic metastasis. Nature. 2015; 527: 329-35.

16. Montecalvo A, Larregina AT, Shufesky WJ, Beer Stolz D, Sullivan MLG, Karlsson JM, et al. Mechanism of transfer of functional microRNAs between mouse dendritic cells via exosomes. Blood. 2012; 119: 756-66.

17. McKelvey KJ, Powell KL, Ashton AW, Morris JM, McCracken SA. Exosomes: mechanisms of uptake. J Circ Biomarkers. 2015; 4: 7. doi: $10.5772 / 61186$.

18. Huang-Doran I, Zhang CY, Vidal-Puig A. Extracellular vesicles: novel mediators of cell communication in metabolic disease. Trends Endocrinol Metab. 2017; 28: 3-18.

19. Müller G. Microvesicles/exosomes as potential novel biomarkers of metabolic diseases. Diabetes Metab Syndr Obes Targets Ther. 2012; 5: $247-82$

20. O'Loughlin AJ, Woffindale CA, Wood MJ. Exosomes and the emerging field of exosome-based gene therapy. Curr Gene Ther. 2012; 12: 262-74.

21. Muylaert DE, Fledderus JO, Bouten CV, Dankers PY, Verhaar MC. Combining tissue repair and tissue engineering; bioactivating implantable cell-free vascular scaffolds. Heart. 2014; 100: 1825-30.

22. Vanden Berg-Foels WS. In situ tissue regeneration: chemoattractants for endogenous stem cell recruitment. Tissue Eng Part B Rev. 2014; 20: 28-39.

23. Vizoso FJ, Eiro N, Cid S, Schneider J, Perez-Fernandez R. Mesenchymal stem cell secretome: toward cell-free therapeutic strategies in regenerative medicine. Int J Mol Sci. 2018; 18: 1852. doi: 10.3390/ijms18091852.

24. Sahu R, Kaushik S, Clement CC, Cannizzo ES, Scharf B, Follenzi A, et al. Microautophagy of cytosolic proteins by late endosomes. Dev Cell. 2011; 20: 131-9.

25. Huotari J, Helenius A. Endosome maturation. EMBO J. 2011; 30: 3481-500.

26. Record M, Subra C, Silvente-Poirot S, Poirot M. Exosomes as intercellular signalosomes and pharmacological effectors. Biochem Pharmacol. 2011; 81: 1171-82.

27. Ghossoub R, Lembo F, Rubio A, Gaillard CB, Bouchet J, Vitale $\mathrm{N}$, et al. Syntenin-ALIX exosome biogenesis and budding into multivesicular bodies are controlled by ARF6 and PLD2. Nat Commun 5: 3477. doi: 10.1038/ncomms4477.

28. Tricarico C, Clancy J, D'Souza-Schorey C. Biology and biogenesis of shed microvesicles. Small GTPases. 2016; 8: 220-32.

29. Record M, Silvente-Poirot S, Poirot M, Wakelam MJO. Extracellular vesicles: lipids as key components of their biogenesis and functions. J Lipid Res. 2018; 59: 1316-24.

30. Kalra H, Simpson RJ, Ji H, Aikawa E, Altevogt P, Askenase P, et al. Vesiclepedia: a compendium for extracellular vesicles with continuous community annotation. PLoS Biol. 2012; 10: e1001450. doi: 10.1371/journal.pbio.1001450.

31. Keerthikumar S, Chisanga D, Ariyaratne D, Al Saffar H, Anand S, Zhao K, et al. ExoCarta: a web-based compen- dium of exosomal cargo. J Mol Biol. 2016; 428: 688-92.

32. Choi DS, Kim DK, Kim YK, Gho YS. Proteomics, transcriptomics and lipidomics of exosomes and ectosomes. Proteomics. 2013; 13: 1554-71.

33. Mathivanan S, Ji H, Simpson RJ. Exosomes: extracellular organelles important in intercellular communication. J Proteom. 2010; 73: 1907-20.
34. Simpson RJ, Jensen SS, Lim JW. Proteomic profiling of exosomes: current perspectives. Proteomics 2008; 8: 4083-99.

35. Pisitkun T, Shen RF, Knepper MA. Identification and proteomic profiling of exosomes in human urine. Proc Natl Acad Sci USA. 2004; 101: 13368-73.

36. Pegtel DM, Cosmopoulos K, Thorley-Lawson DA, van Eijndhoven MA, Hopmans ES, Lindenberg JL, et al. Functional delivery of viral miRNAs via exosomes. Proc Natl Acad Sci USA. 2010; 107: 632833.

37. Raposo G, Nijman HW, Stoorvogel W, Liejendekker R, Harding CV, Melief CJ, et al. B lymphocytes secrete antigen-presenting vesicles. J Exp Med. 1996; 183: 1161-72.

38. Haraszti RA, Didiot M-C, Sapp E, Leszyk J, Shaffer SA, Rockwell $\mathrm{HE}$, et al. High-resolution proteomic and lipidomic analysis of exosomes and microvesicles from different cell sources. J Extracell Vesicles. 2016; 5: 32570. doi: 10.3402/jev.v5.32570.

39. Skotland T, Sandvig K, Llorente A. Lipids in exosomes: Current knowledge and the way forward. Prog Lipid Res. 2017; 66: 30-41.

40. Kahlert C, Melo SA, Protopopov A, Tang J, Seth S, Koch M, et al. Identification of double-stranded genomic DNA spanning all chromosomes with mutated KRAS and p53 DNA in the serum exosomes of patients with pancreatic cancer. J Biol Chem. 2014; 289: 3869-75.

41. Laulagnier K, Vincent-Schneider H, Hamdi S, Subra C, Lankar D, Record M. Characterization of exosome subpopulations from RBL$2 \mathrm{H} 3$ cells using fluorescent lipids. Blood Cells Mol Dis. 2005; 35: 116-21.

42. Colombo M, Moita C, van Niel G, Kowal J, Vigneron J, Benaroch $\mathrm{P}$, et al. Analysis of ESCRT functions in exosome biogenesis, composition and secretion highlights the heterogeneity of extracellular vesicles. J Cell Sci. 2013; 126: 5553-65.

43. Bobrie A, Colombo M, Krumeich S, Raposo G, Théry C. Diverse subpopulations of vesicles secreted by different intracellular mechanisms are present in exosome preparations obtained by differential ultracentrifugation. J Extracell Vesicles. 2012; 1: 18397. doi: $10.3402 /$ jev.v1i0.18397.

44. Kowal J, Arras G, Colombo M, Jouve M, Morath JP, PrimdalBengtson B, et al. Proteomic comparison defines novel markers to characterize heterogeneous populations of extracellular vesicle subtypes. Proc Natl Acad Sci USA. 2016; 113: E968-77.

45. Kosaka N, Iguchi H, Yoshioka Y, Takeshita F, Matsuki Y, Ochiya T. Secretory mechanisms and intercellular transfer of microRNAs in living cells. J Biol Chem. 2010; 285: 17442-52.

46. Johnstone RM, Adam M, Hammond JR, Orr L, Turbide C. Vesicle formation during reticulocyte maturation. Association of plasma membrane activities with released vesicles (exosomes). J Biol Chem. 1987; 262: 9412-20.

47. Zitvogel L, Regnault A, Lozier A, Wolfers J, Flament C, Tenza D, et $a l$. Eradication of established murine tumors using a novel cell-free vaccine: dendritic cell-derived exosomes. Nat Med. 1998; 4: 594600.

48. Thery C, Boussac M, Veron P, Ricciardi-Castagnoli P, Raposo G, Garin J, et al. Proteomic analysis of dendritic cell-derived exosomes: a secreted subcellular compartment distinct from apoptotic vesicles. J Immunol. 2001; 166: 7309-18.

49. Lai RC, Arslan F, Lee MM, Sze NS, Choo A, Chen TS, et al. Exosome secreted by MSC reduces myocardial ischemia/reperfusion injury. Stem Cell Res. 2010; 4: 214-22.

50. Bang C, Thum T. Exosomes: new players in cell-cell communication. Int J Biom Cell Biol. 2012; 44: 2060-4.

51. Gupta SK, Bang C, Thum T. Circulating microRNAs as biomarkers and potential paracrine mediators of cardiovascular disease. Circ Cardiovasc Genet. 2010; 3: 484-8 
52. Thery C. Exosomes: secreted vesicles and intercellular communications. F1000 Biol Rep. 2011; 3: 15. doi: 10.3410/b3-15.

53. Lamparski HG, Metha-Damani A, Yao JY, Patel S, Hsu DH, Ruegg $\mathrm{C}$, et al. Production and characterization of clinical grade exosomes derived from dendritic cells. Journal of Immunological Methods 2002; 270: 211-26.

54. Morse MA, Garst J, Osada T, Khan S, Hobeika A, Clay TM, et al. A phase I study of dexosome immunotherapy in patients with advanced non-small cell lung cancer. J Transl Med. 2005; 3: 9. doi: 10.1186/1479-5876-3-9.

55. Alvarez-Erviti L, Seow Y, Yin H, Betts C, Lakhal S, Wood MJ. Delivery of siRNA to the mouse brain by systemic injection of targeted exosomes. Nat Biotechnol. 2011; 29: 341-5.

56. Shabbir A, Cox A, Rodriguez-Menocal L, Salgado M, Van Badiavas E. Mesenchymal stem cell exosomes induce proliferation and migration of normal and chronic wound fibroblasts, and enhance angiogenesis in vitro. Stem Cells Dev. 2015; 24: 1635-47.

57. Phinney DG, Pittenger MF. Concise review: msc-derived exosomes for cell-free therapy. Stem Cells. 2017; 35: 851-8.

58. Zhang S, Chu WC, Lai RC, Lim SK, Hui JH, Toh WS. Exosomes derived from human embryonic mesenchymal stem cells promote osteochondral regeneration. Osteoarthritis Cartilage. 2016; 24: 2135-40.

59. Bjorge IM, Kim SY, Mano JF, Kalionis B, Chrzanowski W. Extracellular vesicles, exosomes and shedding vesicles in regenerative medicine - a new paradigm for tissue repair. Biomater Sci. 2017; 6: 60-78.

60. Barry FP, Murphy JM. Mesenchymal stem cells: clinical applications and biological characterization. Int J Biochem Cell Biol. 2004; 36: 568-84.

61. Erices A, Conget P, Minguell JJ. Mesenchymal progenitor cells in human umbilical cord blood. Br J Haematol. 2000; 109: 235-42.

62. Gang EJ, Jeong JA, Hong SH, Hwang SH, Kim SW, Yang IH, et al. Skeletal myogenic differentiation of mesenchymal stem cells isolated from human umbilical cord blood. Stem Cells. 2004; 22: 617-24.

63. Pittenger MF, Mackay AM, Beck SC, Jaiswal RK, Douglas R, Mosca $\mathrm{JD}$, et al. Multilineage potential of adult human mesenchymal stem cells. Science. 1999; 284: 143-7.

64. Crapnell K, Blaesius R, Hastings A, Lennon DP, Caplan AI, Bruder SP. Growth, differentiation capacity, and function of mesenchymal stem cells expanded $\mathrm{n}$ serum-free medium developed via combinatorial screening. Exp Cell Res. 2013; 319: 1409-18.

65. Griffin MD, Ryan AE, Alagesan S, Lohan P, Treacy O, Ritter T. Antidonor immune responses elicited by allogeneic mesenchymal stem cells: what have we learned so far? Immunol Cell Biol. 2013; 91: 40-51.

66. Rani S, Ryan AE, Griffin MD, Ritter T. mesenchymal stem cellderived extracellular vesicles: toward cell-free therapeutic applications. Mol Ther. 2015; 23: 812-23.

67. Karp JM, Leng Teo GS. Mesenchymal stem cell homing: the devil is in the details. Cell Stem Cell. 2009; 4: 206-16.

68. Wagner J, Kean T, Young R, Dennis JE, Caplan AI. Optimizing mesenchymal stem cell-based therapeutics. Curr Opin Biotechnol. 2009; 20: 531-6.

69. Williams AR, Hare JM. Mesenchymal stem cells: biology, pathophysiology, translational findings, and therapeutic implications for cardiac disease. Circ Res. 2011; 109: 923-40.

70. Tögel $\mathrm{F}$, Hu Z, Weiss $\mathrm{K}$, Isaac J, Lange $\mathrm{C}$, Westenfelder $\mathrm{C}$. Administered mesenchymal stem cells protect against ischemic acute renal failure through differentiation-independent mechanisms. Am J Physiol Renal Physiol. 2005; 289: F31-42.
71. Tögel F, Weiss $\mathrm{K}$, Yang $\mathrm{Y}$, Hu Z, Zhang $\mathrm{P}$, Westenfelder C. Vasculotropic, paracrine actions of infused mesenchymal stem cells are important to the recovery from acute kidney injury. Am J Physiol Renal Physiol. 2007; 292: F1626-35.

72. Xin H, Li Y, Chopp M. Exosomes/miRNAs as mediating cell-based therapy of stroke. Front Cell Neurosci. 2014; 8: 377. doi: 10.3389/ fncel.2014.00377.

73. Li Y, Liu Z, Xin H, Chopp M. The role of astrocytes in mediating exogenous cell-based restorative therapy for stroke. Glia. 2014; 62: $1-16$.

74. Xin H, Li Y, Liu Z, Wang X, Shang X, Cui Y, et al. MiR-133b promotes neural plasticity and functional recovery after treatment of stroke with multipotent mesenchymal stromal cells in rats via transfer of exosome-enriched extracellular particles. Stem Cells. 2013; 31: 2737-46.

75. Cunningham CJ, Redondo-Castro E, Allan SM. The therapeutic potential of the mesenchymal stem cell secretome in ischaemic stroke. J Cereb Blood Flow Metab. 2018; 38: 1276-92.

76. Lamichhane TN, Sokic S, Schardt JS, Raiker RS, Lin JW, Jay SM. Emerging roles for extracellular vesicles in tissue engineering and regenerative medicine. Tissue Eng Part B Rev. 2015; 21: 45-54.

77. Zhou Y, Xu H, Xu W, Wang B, Wu H, Tao Y, et al. Exosomes released by human umbilical cord mesenchymal stem cells protect against cisplatin-induced renal oxidative stress and apoptosis in vivo and in vitro. Stem Cell Res Ther. 2013; 4: 34. doi: 10.1186/scrt194.

78. Barile L, Lionetti V, Cervio E, Matteucci M, Gherghiceanu M, Popescu LM, et al. Extracellular vesicles from human cardiac progenitor cells inhibit cardiomyocyte apoptosis and improve cardiac function after myocardial infarction. Cardiovasc Res. 2014; 103: 530-41.

79. Reis LA, Borges FT, Simoes MJ, Borges AA, Sinigaglia-Coimbra R, Schor N. Bone marrow-derived mesenchymal stem cells repaired but did not prevent gentamicin-induced acute kidney injury through paracrine effects in rats. PLoS One. 2012; 7: e44092. doi:10.1371/ journal.pone.0044092.

80. Bian S, Zhang L, Duan L, Wang X, Min Y, Yu H. Extracellular vesicles derived from human bone marrow mesenchymal stem cells promote angiogenesis in a rat myocardial infarction model. J Mol Med. 2014; 92: 387-97.

81. Zhang HC, Liu XB, Huang S, Bi XY, Wang HX, Xie LX, et al. Microvesicles derived from human umbilical cord mesenchymal stem cells stimulated by hypoxia promote angiogenesis both in vitro and in vivo. Stem Cells Dev. 2012; 21: 3289-97.

82. Zhang B, Yin Y, Lai RC, Tan SS, Choo AB, Lim SK. Mesenchymal stem cells secrete immunologically active exosomes. Stem Cells Dev. 2014; 23: 1233-44.

83. Mokarizadeh A, Delirezh N, Morshedi A, Mosayebi G, Farshid AA, Mardani K. Microvesicles derived from mesenchymal stem cells: potent organelles for induction of tolerogenic signaling. Immunol Lett. 2012; 147: 47-54.

84. Beer L, Mildner M, Ankersmit HJ. Cell secretome based drug substances in regenerative medicine: when regulatory affairs meet basic science. Ann Transl Med. 2017; 5: 170. doi: 10.21037/ atm.2017.03.50.

85. Schinköthe $\mathrm{T}$, Bloch $\mathrm{W}, \mathrm{Schmidt} \mathrm{A}$. In vitro secreting profile of human mesenchymal stem cells. Stem Cells Dev. 2008; 17: 199-206.

86. Park CW, Kim K-S, Bae S, Son HK, Myung P-K, Hong HJ, et al. Cytokine secretion profiling of human mesenchymal stem cells by antibody array. Int J Stem Cells 2009; 2: 59-68.

87. Nakano N, Nakai Y, Seo TB, Yamada Y, Ohno T, Yamanaka A, et al. Characterization of conditioned medium of cultured bone marrow stromal cells. Neurosci Lett. 2010; 483: 57-61. 
88. Kupcova Skalnikova H. Proteomic techniques for characterisation of mesenchymal stem cell secretome. Biochimie. 2013; 95: 2196-211.

89. Hsiao ST-F, Asgari A, Lokmic Z, Sinclair R, Dusting GJ, Lim SY, et al. Comparative analysis of paracrine factor expression in human adult mesenchymal stem cells derived from bone marrow, adipose, and dermal tissue. Stem Cells Dev. 2012; 21: 2189-203.

90. Du WJ, Chi Y, Yang ZX, Li ZJ, Cui JJ, Song BQ, et al. Heterogeneity of proangiogenic features in mesenchymal stem cells derived from bone marrow, adipose tissue, umbilical cord, and placenta. Stem Cell Res Ther. 2016; 7: 163. doi: 10.1186/s13287-016-0418-9.

91. Eiró N, Sendon-Lago J, Seoane S, Bermúdez MA, Lamelas ML, Garcia-Caballero $\mathrm{T}$, et al. Potential therapeutic effect of the secretome from human uterine cervical stem cells against both cancer and stromal cells compared with adipose tissue stem cells. Oncotarget. 2014; 5: 10692-708. doi: 10.18632/oncotarget.2530.

92. Bermudez MA, Sendon-Lago J, Eiro N, Trevino M, Gonzalez F, Yebra-Pimentel E, et al. Corneal epithelial wound healing and bactericidal effect of conditioned medium from human uterine cervical stem cells. Invest. Ophthalmol Vis Sci. 2015; 56: 983-92.

93. Bermudez MA, Sendon-Lago J, Seoane S, Eiro N, Gonzalez F, Saa J, et al. Anti-inflammatory effect of conditioned medium from human uterine cervical stem cells in uveitis. Exp Eye Res. 2016; 149: 8492.

94. Osugi M, Katagiri W, Yoshimi R, Inukai T, Hibi H, Ueda M. Conditioned media from mesenchymal stem cells enhanced bone regeneration in rat calvarial bone defects. Tissue Eng Part A. 2012; 18: $1479-89$

95. Meyer GP, Wollert KC, Lotz J, Steffens J, Lippolt P, Fichtner S, et al. Intracoronary bone marrow cell transfer after myocardial infarction: 5-year follow-up of the BOOST trial. Circulation. 2008; 118: S764-5.

96. Tateishi-Yuyama E, Matsubara H, Murohara T, Ikeda U, Shintani S, Masaki $\mathrm{H}$, et al. Therapeutic angiogenesis for patients with limb ischaemia by autologous transplantation of bone-marrow cells: a pilot study and a randomised controlled trial. Lancet. 2002; 360: 427-35.

97. Menasché P. Stem cells for clinical use in cardiovascular medicine: current limitations and future perspectives. Thromb Haemost. 2005; 94: 697-701.

98. Zhang M, Methot D, Poppa V, Fujio Y, Walsh K, Murry CE. Cardiomyocyte grafting for cardiac repair: graft cell death and antideath strategies. J Mol Cell Cardiol. 2001; 33: 907-921.

99. Gallagher G, Forrest DL. Second solid cancers after allogeneic hematopoietic stem cell transplantation. Cancer. 2007; 109: 84-92.

100. Friedman DL, Leisenring W, Schwartz JL, Deeg HJ. Second malignant neoplasms following hematopoietic stem cell transplantation. Int $\mathrm{J}$ Hematol. 2004; 79: 229-34.

101. Bhang SH, Lee S, Shin JY, Lee TJ, Jang HK, Kim BS. Efficacious and clinically relevant conditioned medium of human adipose-derived stem cells for therapeutic angiogenesis. Mol Ther. 2014; 22: 862-72.

102. Kim HO, Choi S. Mesenchymal stem cell-derived secretome and microvesicles as a cell-free therapeutics for neurodegenerative disorders. Tissue Eng Regen Med. 2013; 10: 93-101.

103. Yang D, Wang W, Li L, Peng Y, Chen P, Huang H, et al. The relative contribution of paracine effect versus direct differentiation on adipose-derived stem cell transplantation mediated cardiac repair. PLoS ONE. 2013; 8: e59020. doi: 10.1371/journal.pone.0059020.

104. Fukuoka H, Suga H, Narita K, Watanabe R, Shintani S. The latest advance in hair regeneration therapy using proteins secreted by adipose-derived stem cells. Am J Cosmet Surg. 2012; 29: 273-82.

105. Zhou BR, Xu Y, Guo SL, Xu Y, Wang Y, Zhu F, et al. The effect of conditioned media of adipose-derived stem cells on wound healing after ablative fractional carbon dioxide laser resurfacing. BioMed Res Int. 2013; 2013; 519126. doi:10.1155/2013/519126.

106. Park BS, Kim WS, Choi JS, Kim HK, Won JH, Ohkubo F, et al. Hair growth stimulated by conditioned medium of adipose-derived stem cells is enhanced by hypoxia: evidence of increased growth factor secretion. Biomed Res. 2010; 31: 27-34.

107. Ho JCY, Lai WH, Li MF, Au KW, Yip MC, Wong NLY, et al. Reversal of endothelial progenitor cell dysfunction in patients with type 2 diabetes using a conditioned medium of human embryonic stem cell-derived endothelial cells. Diabetes Metab Res Rev. 2012; 28: 462-73.

108. Di Santo S, Yang Z, Wyler von Ballmoos M, Voelzmann J, Diehm $\mathrm{N}$, Baumgartner I, et al. Novel cell-free strategy for therapeutic angiogenesis: in vitro generated conditioned medium can replace progenitor cell transplantation. PLoS ONE. 2009; 4: e5643. doi: 10.1371/journal.pone.0005643.

109. Mirabella T, Cilli M, Carlone S, Cancedda R, Gentili C. Amniotic liquid derived stem cells as reservoir of secreted angiogenic factors capable of stimulating neo-arteriogenesis in an ischemic model. Biomaterials. 2011; 32: 3689-99.

110. Wuchter P, Bieback K, Schrezenmeier H, Bornhäuser M, Müller LP, Bönig $\mathrm{H}$, et al. Standardization of good manufacturing practice-compliant production of bone marrow-derived human mesenchymal stromal cells for immunotherapeutic applications. Cytotherapy. 2015; 17: 128-39.

111. Yde P, Mengel B, Jensen MH, Krishna S, Trusina A. Modeling the $\mathrm{NF}-\mathrm{kB}$ mediated inflammatory response predicts cytokine waves in tissue. BMC Syst Biol. 2011; 5: 115. doi: 10.1186/1752-0509-5115.

112. Khosravi A, Cutler CM, Kelly MH, Chang R, Royal RE, Sherry RM, et al. Determination of the elimination half-life of fibroblast growth factor-23. J Clin Endocrinol Metab. 2007; 92: 2374-7.

113. Pawitan JA. Prospect of stem cell conditioned medium in regenerative medicine. Biomed Res Int. 2014; 2014: 965849. doi: $10.1155 / 2014 / 965849$.

114. Li M, Luan F, Zhao Y, Hao H, Liu J, Dong L, et al. Mesenchymal Stem cell-conditioned medium accelerates wound healing with fewer scars. Int Wound J. 2017; 14: 64-73.

115. Park CM, Kim MJ, Kim SM, Park JH, Kim ZH, Choi YS. Umbilical cord mesenchymal stem cell-conditioned media prevent muscle atrophy by suppressing muscle atrophy- related proteins and ROS generation. In Vitro Cell Dev Biol Anim. 2016; 52: 68-76.

116. Kim MJ, Kim ZH, Kim SM, Choi YS. Conditioned medium derived from umbilical cord mesenchymal stem cells regenerates atrophied muscles. Tissue Cell. 2016; 48: 533-43.

117. Sriramulu S, Banarjee A, Di Liddo R, Jothimani G, Gopinath M, Murugesan $\mathrm{R}$, et al. Concise review on clinical applications of conditioned medium derived from human umbilical cordmesenchymal stem cells (UC-MSCs). Int J Hematol Oncol Stem Cell Res. 2018; 12: 230-4.

118. Shen C, Lie P, Miao T, Yu M, Lu Q, Feng T, et al. Conditioned medium from umbilical cord mesenchymal stem cells induces migration and angiogenesis. Mol Med Rep. 2015; 12: 20-30.

119. Thery C, Ostrowski M, Segura E. Membrane vesicles as conveyors of immune responses. Nat Rev Immunol. 2009; 9: 581-93.

120. Qin J, Xu Q. Functions and applications of exosomes. Acta Pol Pharm. 2014; 71: 537-43.

121. Li P, Kaslan M, Lee SH, Yao J, Gao Z. Progress in exosome isolation techniques. Theranostics. 2017; 7: 789-803.

122. Stremersch S, De Smedt SC, Raemdonck K. Therapeutic and diagnostic applications of extracellular vesicles. J Control Release. 2016; 244: 167-83. 
123. Farooqi AA, Desai NN, Qureshi MZ, Librelotto DRN, Gasparri ML, Bishayee A, et al. Exosome biogenesis, bioactivities and functions as new delivery systems of natural compounds. Biotechnol Adv. 2018; 36: 328-34.

124. Adamiak M, Sahoo S. Exosomes in myocardial repair: advances and challenges in the development of next-generation therapeutics. Mol Ther. 2018; 26: 1635-43.

125. Zhang B, Wu X, Zhang X, Sun Y, Yan Y, Shi H, et al. Human umbilical cord mesenchymal stem cell exosomes enhance angiogenesis through the Wnt4/b-catenin pathway. Stem Cell Trans Med. 2015; 4: 513-22.

126. Toh WS, Lai RC, Hui JHP, Lim SK. MSC exosome as a cell-free MSC therapy for cartilage regeneration: Implications for osteoarthritis treatment. Semin Cell Dev Biol. 2017; 67: 56-64.

127. Liu XS, Chopp M, Zhang RL, Zhang ZG. MicroR-NAs in cerebral ischemia-induced neurogenesis. J Neuropathol Exp Neurol. 2013; 72: 718-22.

128. Zhang R, Chopp M, Zhang ZG. Oligodendrogenesis after cerebral ischemia. Front Cell Neurosci. 2013; 7: 201. doi: 10.3389/ fncel.2013.00201.

129. Zhang ZG, Chopp M. Exosomes in stroke pathogenesis and therapy. J Clin Invest. 2016; 126: 1190-7.

130. Teng X, Chen L, Chen W, Yang J, Yang Z, Shen Z. Mesenchymal stem cell-derived exosomes improve the microenvironment of infarcted myocardium contributing to angiogenesis and anti-inflammation. Cell Physiol Biochem. 2015; 37: 2415-24. 